\title{
ДІАГНОСТИКА ТА ХІРУРГІЧНА КОРЕКЦІЯ АТИПОВИХ ПРОЯВІВ ГАСТРОЕЗОФАГЕАЛЬНОЇ РЕФЛЮКСНОЇ ХВОРОБИ
}

\author{
М. М. Велігоцький', В. В. Грубник², В. В. Комарчук', Є. В. Комарчук', \\ М. Р. Параняк², В. В. Грубник² \\ ${ }^{1}$ Харківська медична академія післядипломної освіти, \\ ${ }^{2}$ Одеський національний медичний університет

\section{DIAGNOSTICS AND SURGICAL TREATMENT OF ATYPICAL MANIFESTATION OF GASTROESOPHAGEAL REFLUX DISEASE}

\author{
M. M. Veligotskiy', V. V. Grubnik ${ }^{2}$, V. V. Komarchuk ${ }^{1}$, Ye. V. Komarchuk ${ }^{1}$, \\ M. R. Paranyak, V. V. Grubnik ${ }^{2}$ \\ ${ }^{1}$ Kharkiv Medical Academy of Postgraduate Education, \\ ${ }^{2}$ Odessa National Medical University
}

\begin{abstract}
Рефрерат
У $10 \%$ пацієнтів при гастроезофагеальній рефрюксній хворобі (ГЕРХ) відсутні типові прояви захворювання, а основні симптоми виявляють у дихальній, серцево-судинній системах, ЛОР-органах.

Мета. Покращення діагностичного алгоритму при виявленні позастравохідних проявів ГЕРХ; встановлення ефективності лапароскопічної фрундоплікації у хворих за різних видів гастроезофагеального рефлюксу (ГЕР).

Матеріали і методи. 3 використанням опитувальників якості життя (ЯЖ) SF-36 та GERD-HRQL оцінювали віддалені результати консервативної терапії та хірургічного лікування пацієнтів за наявності респіраторних та ЛОР проявів ГЕРХ.

Результати. Більш суттєве покращення фізичного та психологічного компонентів ЯЖ відзначене у хворих, яким виконували лапароскопічну фундоплікацію. За опитувальником GERD-HRQL, ЯЖ хворих після хірургічного лікування покращилась через 6 міс - $3(16,4 \pm 5,3)$ до $(6,2 \pm 0,6)$ бала $(p<0,001)$, через 12 міс - до $(6,4 \pm 0,8)$ бала $(p<0,001)$; після консервативної терапії через 6 міс - з $(15,9 \pm 6,6)$ до $(9,2 \pm 1,9)$ бала $(p<0,001)$, через 12 міс - до $(11,4 \pm 1,5)$ бала $(p<0,05)$.

Висновки. Лапароскопічна фундоплікація порівняно з консервативною терапією більш ефективний метод лікування пацієнтів за наявності позастравохідних проявів ГЕРХ.

Ключові слова: гастроезофагеальна рефлюксна хвороба; позастравохідні прояви; езофаго-рН-імпеданс моніторинг; лапароскопічна фундоплікація.

Abstract

In $10 \%$ of patients with gastroesophageal reflux disease (GERD) typical symptoms are absent, and main symptoms are respiratory, cardiovascular and otolaryngological complaints.

Objective. To improve the diagnostical algorithm of detection of extraesophageal symptoms of the GERD, to assess the efficacy of laparoscopic fundoplication in patients with different types of gastroespohageal reflux (GER).

Matherials and methods. Quality of life (QL) assessment surveys SF-36 and GERD-HRQL were used to evaluate long-term results of conservative and surgical treatment of patients with respiratory and otolaryngological symptoms of GERD.

Results. More significant improvement of physical and psychological components of QL was detected in patients who underwent laparoscopic fundoplication. According to GERD-HRQL survey, QL of patients after surgery improved within 6 months from (16.4 \pm 5.3 ) up to $(6.2 \pm 0.6)(p<0.001)$, within 12 months - up to $(6.4 \pm 0.8)(p<0.001)$; after conservative treatment within 6 months - from $(15.9 \pm$ $6.6)$ up to $(9.2 \pm 1.9)(p<0.001)$, within 12 months - up to $(11.4 \pm 1.5)(p<0.05)$.

Conclusion. Laparoscopic fundoplication is more effective than the conservative treatment of patients with extraesophageal symptoms of GERD.

Keywords: gastroesophageal reflux disease; extraesophageal symptoms; esophago-pH-impedance monitoring; laparoscopic fundoplication.
\end{abstract}

Діагностика ГЕРХ за наявності типових симптомів, зокрема, печії, відрижки повітрям чи кислим, дисфагії, нудоти не викликає значних труднощів. Алгоритм діагностичного обстеження пацієнтів ретельно відпрацьований [1].

Надзвичайно важливим і складним є питання діагностики атипових проявів ГЕРХ у вигляді респі- раторних, кардіальних та ЛОР симптомів, що виявляють майже у 10\% пацієнтів [2]. Лікувальна тактика за таких клінічних проявів $є$ предметом дискусії, оскільки і довготривала консервативна терапія, і хірургічне лікування можуть супроводжуватись виникненням тяжких ускладнень [3].

У системному огляді здійснено спробу проаналізувати вплив різ- них видів ГЕР на виникнення типових та атипових симптомів ГЕРХ [4]. Встановлено, що у 59 - 67\% пацієнтів, яким не проводили консервативну антирефлюксну терапію, відзначали рефлюкс кислого вмісту, у пацієнтів 3 симптомами ГЕРХ, які застосовували інгібітори протонної помпи (ІПП), частота рефлюксу слабокислого та слаболужного вмісту 
становила 76 - 84\%. У зв'язку з малою кількістю спостережень автори не зробили чітких висновків щодо характеристики рефлюксу за наявності позастравохідних симптомів ГЕРХ. Доведено, що навіть рефлюкс газу здатний спричиняти печію, проте, роль такого ГЕР у виникненні позастравохідних проявів ГЕРХ не 3'ясована [5].

Мета дослідження: покращення діагностичного алгоритму за наявності позастравохідних проявів ГЕРХ; встановлення ефективності лапароскопічної фундоплікації у хворих за різних видів ГЕР.

\section{МАТЕРІАЛИ I МЕТОДИ ДОСЛІДЖЕННЯ}

Дослідження проведене за період з 2015 по 2017 р. на базі відділення хірургії № 1 Харківської міської клінічної лікарні швидкої допомоги імені проф. О. І. Мещанінова та відділення загальної хірургії Одеської обласної клінічної лікарні. У дослідження включені пацієнти, у яких діагностовано ГЕРХ та іiі респіраторні і ЛОР прояви. Як імовірні позастравохідні прояви ГЕРХ відзначали: кашель нез'ясованого походження, періодичне відчуття наявності «комка» в горлі, зміна тембру голоса, риніт, синусит. Деякі пацієнти раніше зверталися по медичну допомогу до фахівців відповідного профілю, їм проводили базову терапію, проте, лікувальні заходи виявились малоефективними.

В Одеській обласній клінічній лікарні хворим проводили цілодобову рН-метрію стравоходу 3 метою встановлення патологічного ГЕР, рентгенологічне дослідження стравоходу, шлунка, дванадцятипалої кишки - для виявлення грижі стравохідного отвору діафрагми (ГСОД) як основної причини ГЕРХ [6], га- стродуоденофіброскопію - для виявлення езофагіту.

У Харківській міській клінічній лікарні як альтернативу цілодобовій pH-метрії стравоходу використовували цілодобовий мультиканальний езофаго-рН-імпеданс моніторинг. Метод дозволяє виявити ГЕР за різного рН рефлюксанту та визначити рівень ГЕР. Діагностику проводили з використанням ацидогастрографа $\mathrm{pH}-\mathrm{Z}$, розробленого медикотехнічним колективом ТОВ «Старт» (Вінниця) під методичним керівництвом проф. В. М. Чорнобрового. Для дослідження використовували добовий езофаго-рН-імпеданс моніторинг за допомогою мікрозонда з 2 або 3 датчиками рH і 4 парами датчиків для вимірювання імпедансу на висоті 3, 5, 7 і 15 см від верхнього краю нижнього стравохідного сфінктера. Після проведення комплексу діагностичних заходів пацієнтам здійснювали лапароскопічну фундоплікацію за Nissen. За наявності у пацієнтів ГСОД I і II ступеня виконували крурорафію, ГСОД III ступеня - пластику дефекту з використанням сітчастого імплантата. За цим алгоритмом виконані лапароскопічні втручання у 75 пацієнтів 3 атиповими проявами ГЕРХ, в тому числі 51 - в Одесі та 24 - у Харкові. Вік пацієнтів у середньому $(51 \pm 4,5)$ року, чоловіків було 31 (41,3\%), жінок - 44 (58,7\%). Ці хворі включені до основної групи. В контрольну групу відібрані 16 пацієнтів 3 діагНостованою ГЕРХ та позастравохідними проявами захворювання, яким впродовж 12 тиж проводили консервативну антирефлюксну терапію з використанням ІПП, антацидів, прокінетиків. Пацієнтам було повідомлено, що по завершенні курсу терапії можливе відновлення симптомів. За такої ситуації рекомендова- но продовжувати застосування ІПП. Для оцінки віддалених результатів лікування використовували опитувальник Яж SF-36 та опитувальник GERD-HRQL. Результати оцінювали через 6 і 12 міс після лікувальння.

\section{РЕЗУЛЬТАТИ ТА ÏХ ОБГОВОРЕННЯ}

Під час рентгенологічного дослідження стравоходу і шлунка в усіх пацієнтів основної групи було виявлено ГСОД. 351 хворого, оперованого в Одеській клініці, ГСОД І ступеня діагностована у 9, II ступеня - у 22, III ступеня - у 20. Індекс De Meester за даними $\mathrm{pH}$-метрії становив у середньому 78,2 $\pm 16,1$.

У зв'язку з можливістю більш детальної характеристики 24 хворих, оперованих у Харкові, дані рентгенологічного дослідження стравоходу і шлунка та інтерпретація результатів імпеданс $\mathrm{pH}-$ моніторингу наведені у табл. 1.

Під час виконання лапароскопічної фундоплікації у хворих основної групи ускладнень не було. Тривалість лікування хворого у стаціонарі становила від 1 до 8 днів, у середньому $(4,3 \pm 1,4)$ дня. Тривалість оперативного втручання у середньому $(85,2 \pm 11,3)$ хв. Після операції в одного пацієнта виник рецидив ГСОД, періодично виникали типові симптоми ГЕРХ, зокрема, печія, відчуття «комка» в горлі. Пацієнту призначена консервативна терапія з використанням ІПП, оскільки він відмовився від повторного оперативного втручання. Зміни клінічних симптомів після проведення лікувальних заходів наведені у табл. 2.

Отже, регрес типових симптомів ГЕРХ більш виражений порівняно 3 респіраторними та ЛОР проявами захворювання у хворих обох груп ( $<$ 0,05). 3 атипових симпто-

Таблиця 1. Кількісні показники ГЕР впродовж доби на тлі ГСОД

\begin{tabular}{|c|c|c|c|c|}
\hline \multirow{2}{*}{ Характеристики ГЕР } & \multirow{2}{*}{ Кількість ГЕР у нормі } & \multicolumn{3}{|c|}{ Кількість ГЕР за ступеня ГСОД } \\
\hline & & $I(n=4)$ & II (n=12) & III $(n=8)$ \\
\hline Кислий & 50 і менше & $89-113$ & $95-136$ & $97-166$ \\
\hline Слабо-кислий & 33 і менше & $96-135$ & $88-166$ & $76-165$ \\
\hline Слабо-лужний & 15 і менше & $7-17$ & $6-21$ & $11-23$ \\
\hline Надрефлюкс & менше 4 & $2-7$ & $2-9$ & $7-12$ \\
\hline Рідинний & 55 і менше & $32-64$ & $37-62$ & $34-75$ \\
\hline Газовий & 30 і менше & $55-67$ & $76-89$ & $92-111$ \\
\hline Змішаний (рідина і газ) & 42 і менше & $68-97$ & $67-112$ & $64-132$ \\
\hline Індекс De Meester & 14,7 і менше & $87-159,5$ & $109-175$ & $112-256$ \\
\hline
\end{tabular}


Таблиця 2. Оцінка результатів лікування ГЕРХ

\begin{tabular}{|c|c|c|c|c|c|c|}
\hline \multirow{3}{*}{ Симптом } & \multirow{3}{*}{$\begin{array}{c}\text { Строки } \\
\text { спостереження }\end{array}$} & \multicolumn{5}{|c|}{ Кількість спостережень в групах } \\
\hline & & \multicolumn{2}{|c|}{ основній $(n=75)$} & \multicolumn{2}{|c|}{ контрольній $(\mathrm{n}=16)$} & \multirow{2}{*}{$p^{*}$} \\
\hline & & абс. & $\%$ & абс. & $\%$ & \\
\hline \multirow{3}{*}{$\begin{array}{l}\text { Виражена печія або } \\
\text { відрижка кислим }\end{array}$} & До лікування & 34 & 45,3 & 9 & 56,3 & 0,302 \\
\hline & Через 6 міс & 2 & 2,7 & 2 & 12,5 & 0,141 \\
\hline & Через 12 міс & 2 & 2,7 & 4 & 25,0 & 0,008 \\
\hline \multirow{3}{*}{ Кашель без задишки } & До лікування & 63 & 84,0 & 12 & 75,0 & 0,886 \\
\hline & Через 6 міс & 7 & 9,3 & 6 & 37,5 & 0,010 \\
\hline & Через 12 міс & 8 & 10,7 & 7 & 43,8 & 0,004 \\
\hline \multirow{3}{*}{ Кашель з задишкою } & До лікування & 11 & 14,7 & 3 & 18,8 & 0,464 \\
\hline & Через 6 міс & 5 & 6,7 & 2 & 12,5 & 0,357 \\
\hline & Через 12 міс & 4 & 5,3 & 2 & 12,5 & 0,284 \\
\hline \multirow{3}{*}{$\begin{array}{l}\text { Відчуття наявності } \\
\text { «омка» в горлі }\end{array}$} & До лікування & 59 & 78,8 & 11 & 68,8 & 0,879 \\
\hline & Через 6 міс & 9 & 12,0 & 6 & 37,5 & 0,022 \\
\hline & Через 12 міс & 7 & 9,3 & 8 & 50,0 & 0,001 \\
\hline \multirow{3}{*}{ Зміна тембру голоса } & До лікування & 38 & 50,7 & 9 & 56,3 & 0,302 \\
\hline & Через 6 міс & 6 & 8,0 & 5 & 31,2 & 0,141 \\
\hline & Через 12 міс & 4 & 5,3 & 6 & 37,5 & 0,008 \\
\hline \multirow{3}{*}{ Риніт і/або синусит } & До лікування & 8 & 10,7 & 2 & 12,5 & 0,886 \\
\hline & Через 6 міс & 4 & 5,3 & 2 & 12,5 & 0,010 \\
\hline & Через 12 міс & 3 & 4,0 & 2 & 12,5 & 0,004 \\
\hline
\end{tabular}

Примітка. $\quad$ *-точний індекс Фішера.

мів ГЕРХ найбільш виражений ефект оперативного втручання спостерігали щодо зменшення вираженості кашлю та відчуття «комка» в горлі. У хворих контрольної групи відзначене суттєве зменшення частоти респіраторних та ЛОР симптомів через 6 міс ( $<0,05)$, проте, через 12 міс спостерігали тенденцію до відновлення скарг. Після операції 22 (84,6\%) пацієнта задоволені результатом лікування, у 4 (15,4\%) - хірургічне лікування не виправдало очікуваного ефекту. Після консервативної терапії задоволені результатом лікування 5 (31,2\%) пацієнтів. Зміни ЯЖ пацієнтів основної групи наведені на рис. 1.

При статистичному аналізі показників опитувальника SF-36 відзначене достовірне покращення фізичного та психологічного компонен-

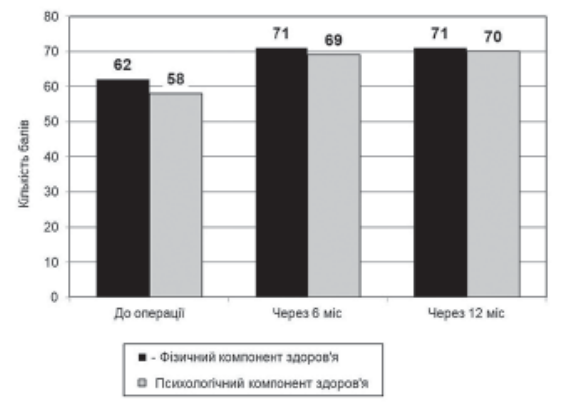

Pис. 1.

Оцінка ЯЖ оперованих пацієнтів основної групи за даними опитувальника SF-36. тів здоров'я пацієнтів через 6 та 12 міс ( $<$ 0,05) після виконання фундоплікації.

У контрольній групі спостерігали достовірне покращення фізичного та психологічного компонентів здоров'я (рис. 2) через 6 міс після проведення лікувальних заходів $(\mathrm{p}<0,05)$. Проте, через 12 міс більшість 3 них скаржилися на поступове погіршення стану, про що свідчило зменшення показників ЯЖ порівняно з попередніми. Проте, за даними статистичного аналізу результатів лікування ефективність консервативної терапії через 12 міс була значущою (р $<0,05)$.

За даними опитувальника SF-36, під час звернення по медичну допомогу ЯЖ хворих обох груп суттево не різнилася ( $>$ > 0,05), не було сутте-

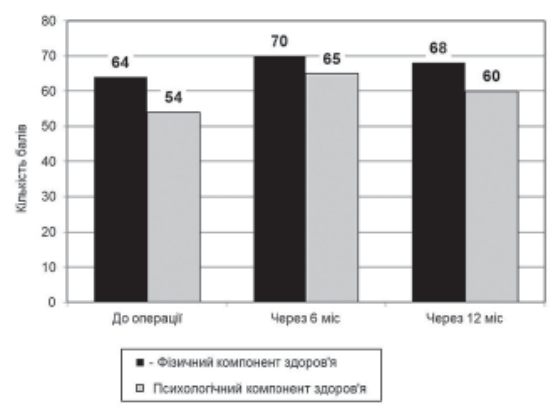

Pис. 2.

Оцінка ЯЖ пацієнтів контрольної групи за даними опитувальника SF-36. вих розбіжностей і через 6 міс після лікування. Проте, через 12 міс після хірургічного лікування ЯЖ пацієнтів покращувалася, після консервативної терапії ефект лікування зменшувався. За статистичним аналізом результатів лікування через 12 міс відзначали достовірно більші показники ЯЖ пацієнтів після лапароскопічної фундоплікації.

За даними опитувальника GERDHRQL, у пацієнтів після лапароскопічної фундоплікації ЯЖ покращилась $3(16,4 \pm 5,3)$ до $(6,2 \pm 0,6)$ бала (р $<0,001)$ - через 6 міс та до $(6,4 \pm 0,8)$ бала (p < 0,001) - через 12 міс. У пацієнтів контрольної групи виявлені такі зміни показника: $(15,9 \pm 6,6)$ бала - на момент звернення по медичну допомогу, $(9,2 \pm 1,9)$ бала - через 6 міс $(\mathrm{p}<0,001),(11,4 \pm 1,5)$ бала - через 12 міс ( $<0,05)$. Тобто, результати лікування достовірно кращі в основній групі.

Виникнення та прогресування позастравохідних респіраторних проявів ГЕРХ зумовлене двома основними механізмами: ваговагальним рефлексом і мікроаспірацією [7]. Рефлекторний механізм пояснюється спільністю іннервації стравоходу та бронхіального дерева блукаючим нервом (n. vagus). Подразнення рефлексогенних вагусних зон слизової оболонки стравоходу хло- 
ристоводневою кислотою з подальшою передачею збудження по еферентних парасимпатичних шляхах в бронхі провокує виникненням приступів кашлю і задишки. При патологічному ГЕР можливе ретроградне переміщення рефлюксанту в просвіті стравоходу до рівня гортанної частини глотки та ротової порожнини. За такої ситуації можлива мікро- та макроаспірація рефлюксанту у верхні дихальні шляхи з виникненням респіраторних симптомів [7]. Виникнення ЛОР проявів ГЕРХ пов'язане з періодичним потраплянням рефлюксанту вище верхнього стравохідного сфінктера. Оскільки слизова оболонка на цьому рівні немає захисних механізмів від впливу хлористоводневої кислоти, навіть одноразове потрапляння рефлюксанту з кислим рН вважають патологічним [8].

За наявності у пацієнтів ГЕРХ першочерговим є застосування консервативної антирефлюксної терапіі,

\section{ЛITEPATYPA/REFERENCES}

1. Veligotskiy NN, Gorbulich AV. Diagnostika i hirurgicheskoe lechenie gastroezofagealnoy reflyuksnoy bolezni. Kharkov,2009.24 s. [In Russian]

2. Duffy JP, Maggard M, Hiyama DT, Atkinson JB. Laparoscopic Nissen fundoplication improves quality of life in patients with atypical symptoms of gastro - esophageal reflux. Am Surg. 2003;69(10):833-8.

3. Garg SK, Gurusamy KS. Laparoscopic fundoplication surgery versus medical management for gastro-esophageal reflux disease (GERD) in adults. Cochrane Database Syst Rev. 2015;5(11): doi: 10.1002/14651858.CD003243.

4. Boeckxstaens GE, Smout A. Systematic review: role of acid, weakly acidic and weakly alkaline reflux in gastro-oesophageal reflux disease. Aliment Pharmacol Ther. 2010;(32):334-43.

5. Bredenoord AJ, Weusten BL, Curvers WL, Timmer R, Smout AJ. Determinants of perception of heartburn and regurgitation. Gut. 2006;55(3):313-8.

6. Oshima T, Miwa H. Pathogenesis of gastro-esophageal reflux disease. Nihon Rinsho. 2007;65(5):797-801. ше зниження рН рефлюксанту і не спрямована на зменшення частоти ГЕР. Консервативна терапія ефективно не впливає на механізм мікро- та макроаспірації рефлюксанту, вміст шлунку періодично потрапляє вище верхнього стравохідного сфінктера та, імовірно, справляє патологічний влив на ЛОР-органи.

\section{ВИсновкИ}

1. Лапароскопічна фундоплікація - ефективний метод лікування пацієнтів за наявності атипових проявів ГЕРХ.

2. Використання імпеданс-рHмоніторингу дозволяє суттево покращити підхід до встановлення показань до виконання лапароскопічної фундоплікації у пацієнтів за наявності атипових симптомів ГЕРХ.

3. Лапароскопічна фундоплікація $є$ методом вибору за наявності у пацієнтів вираженого некислого ГЕР та атипових проявів ГЕРХ Gastroenterol Hepatol (N Y). 2013;9(5):311-3.

8. Kizim VV, Boenko SK, Yurenko EA. Metaanaliz kliniko-morfologicheskih proyavleniy laringofaringealnogo reflyuksa. Zhurnal vushnih, nosovih i gorlovih hvorob. 2011;(3):110-1 [In Russian].

9. Katz PO, Gerson LB, Vela MF. Diagnosis and Management of Gastroesophageal Reflux Disease. Am J Gastroenterol. 2013;(108):30828.

10. Del Genio G, Tolone S, Del Genio F, Rossetti G, Brusciano L, Pizza $F$, et al. Total fundoplication controls acid and nonacid reflux: evaluation by pre- and postoperative $24-\mathrm{h} \mathrm{pH}$-multichannel intraluminal impedance. Surg Endosc. 2008;22:2518-23.

11. Grubnik VV, Malinovskiy AV. Kriticheskie aspektyi laparoskopicheskoy hirurgii gastroezofagealnoy reflyuksnoy bolezni i gryizh pischevodnogo otverstiya diafragmyi. Odesa:VMV-tipografiya, 2015. 106 p. [In Russian]. 